\title{
THE EFFECTIVENESS TEST OF TURMERIC EXTRACT TOWARD BACILUS CEREUS BACTERIA WITH THE COMPARISON OF CIPROFLOXACIN
}

\author{
Uji Efektivitas Ekstrak Rimpang Kunyit Terhadap Bakteri Bacillus Cereus \\ Dengan Pembanding Ciprofloxacin
}

\section{RISYAD RIZKI MAULIDI, FRISDAYANTI BR GINTING, NOVITA HELSHINTA DEWI PANGARIBUAN, PRINCESSA FATH SHERIDAN, YOLANDA ELIZA PUTRI LUBIS}

Study Program of Medical Education, Faculty of Medicine, Universitas Prima Indonesia Email: risyadrizkim112233@gmail.com

\begin{abstract}
This research aims to find out effectiveness test of turmeric rhizome in concentration of $25 \%$, $50 \%, 75 \%$ and $100 \%$ toward Bacillus cereus bacterial and Ciprofloxacin the same concentration as the comparison. Bacillus cereus Bacteria is a gram-positive rod-shaped bacteria and it is dangerous for humans. This research was conducted with an experimental method with post-test only design and sampling using purposive sampling method. The effectiveness test of turmeric rhizome extract toward Bacillus cereus bacteria was carried out by diffusion using disc paper by calculating the diameter of the bacterial inhibition zone against disc paper that had been moistened with turmeric rhizome extract or Ciprofloxacin solution. The results obtained in this research were carried out with the Post Hoc test, the test was found that there were significant differences from each treatment given with a 95\% confidence index. In bacteria treated with $25 \%$ ciprofloxacin toward Bacillus cereus, the effectiveness was above $50 \%$ turmeric rhizome extract and under $75 \%$ turmeric extract. Turmeric extract of $75 \% 10.6$ $\mathrm{mm}$ had bacterial effect as Ciprofloxacin $25 \%$ of $10.1 \mathrm{~mm}$ toward the growth of Bacillus cereus bacterial.
\end{abstract}

Keywords: Antibacterial, Turmeric extract, Bacillus cereus.

\begin{abstract}
Abstrak Penelitian ini bertujuan untuk mengetahui uji efektivitas dari ekstrak rimpang kunyit pada konsentrasi 25\%, 50\%, 75\% dan 100\% terhadap bakteri Bacillus cereus dengan Ciprofloxacin konsentrasi yang sama sebagai pembandingnya. Bakteri Bacillus cereus merupakan bakteri gram positif berbentuk batang dan berbahaya bagi manusia. Penelitian ini dilakukan dengan metode eksperimental dengan desain post-test only design dan pengambilan sampel menggunakan metode Purposive sampling. Uji efektivitas ekstrak rimpang kunyit terhadap bakteri Bacillus cereus dilakukan dengan cara difusi menggunakan kertas cakram, yaitu dengan menghitung diameter zona hambat bakteri terhadap kertas cakram yang sudah dibasahi dengan ekstrak rimpang kunyit maupun larutan Ciprofloxacin. Hasil yang didapat pada penelitian ini yang dilakukan dengan uji Post Hoc, Test tersebut dijumpai bahwa terdapat perbedaan yang bermakna dari setiap perlakuan yang diberikan dengan indeks kepercayaan 95\%. Pada bakteri yang diberi perlakuan ciprofloxacin $25 \%$ terhadap Bacillus cereus, efektivitas yang didapat berada diatas ektrak rimpang kunyit $50 \%$ dan berada dibawah ektrak rimpang kunyit $75 \%$. Ekstrak rimpang kunyit 75\% 10.6 mm memiliki efek antibakteri sama dengan Ciprofloxacin $25 \%$ yaitu $10.1 \mathrm{~mm}$ terhadap pertumbuhan bakteri Bacillus cereus.
\end{abstract}

Kata Kunci: Antibakteri, Ekstrak Rimpang Kunyit, Bacillus cereus. 



\section{INTRODCUTION}

Traditional medicine is an alternative medicine from plant which has been used by society in various parts of the world to treat several diseases. According to a WHO (World Health Organization) survey, it is stated that $80 \%$ of the world's 100 inhabitants have used herbal medicines (Pangemanan, ., \& Budiarso, 2016). Based on Permenkes (Ministry of Health regulations) No. 007 of 2012 concerning traditional medicine has been used for generations and is useful as a treatment according to norms circulating in the community. Traditional medicine is in the form of whole ingredients which can come from nature (Yusnidar, 2017). Turmeric (Curcuma domestica VALET) can be used as a Family Medicinal Plant (TOGA) which is very useful as a correctional effort in family health (Rukmana, 1995). Turmeric consists of roots, rhizomes, stems, leaves, flower stalks and flower buds. The type of fibrous turmeric root (radix adventica) and the shape is like a thread connected to the turmeric rhizome (Rukmana, 1995). The efficacy of turmeric as a medicine is due to its curcuminoid compound and its essential oils which are antioxidant, antitumor, anticancer, antimicrobial, antiseptic and antiinflammatory (Balittro \& Hartati, 2013). In essential oils contained phenol derivatives namely hydroxyl and carbonyl functional groups are used as antibacterial (Yuliati, 2016). Curcumin activity results have the ability to regulate inflammatory cytokines, protein-kinases, enzymes, transcription factors, and growth factors (Mutiah, 2015). There are three components were found in turmeric rhizome, namely Curcumin, Desmetoksikurkumin and BisDesmetoksikurkumin. Turmeric rhizome contains around $3 \%$ of essential oil content and $10 \%$ of curcuminoid content $(\mathrm{H}$. Widyaningrum, 2011). Curcumin is a polyphenol compound (1,7-bis (4 'hydroxy-3'-methoxyphenyl) -, 6heptadiene-3,5-dion). Polyphenols have a structure generally divided into flavonoids and nonflavanoids. Flavonoids-2-alls, flavonols, and tannins as polyphenols which have greater microbial inhibitory activity than other polyphenols and some polyphenols can also inhibit virulence. Turmeric rhizomes contain active ingredients which can be used as antibacterial (Nadifah, Farida Muhajir, \& Retnoningsih, 2018).

The genus of Bacillus cereus belongs to a gram-positive, aerobic chain. Bacillus cereus is usually found in food such as fried rice which has been inhabited for hours at room temperature. Thus, these bacteria cause "fried rice syndrome" (Brooks, 2013).

Toxic food can cause gastrointestinal disorders because it is usually contaminated by Bacillus cereus. This occurs due to the presence of enterotoxins contained in the food consumed. The presence of enterotoxins in food is usually due to the presence of endospore. This endospore is not completely turned off by high temperatures when cooking food (Yuliati, 2016).

Pathogenesis of Bacillus cereus, The soil organism which often contaminates rice is Bacillus cereus. Then in the logphase growth (sporulation), bacterial spores grow and vegetative cells in the bacteria release toxins. The incubation period of diarrhea is about 1-24 hours. Treatment for the Bacillus cereus bacteria is partly resistant to penicillin containing $\beta$ lactamase. Effective alternatives to penicillin are doxycycline, erythromycin or ciprofloxacin (Brooks, 2013).

Ciprofloxacin is antibiotic group of second generation broad-spectrum florokuinolone that functions as an antiinfective or synthetic antibiotic. Ciprofloxacin works by inhibiting the growth of DNA-gyrase. Thus, it can stop the metabolism of germs. Ciprofloxacin is absorbed mainly in the small intestine and the peak concentration after 60-90 minutes later the results of its metabolites are excreted in urine and feces (Kementerian 
Kesehatan RI, 2008). Ciprofloxacin Antibiotic Medication is a therapy classified as effective against bacteria with a clinical cure rate of $98 \%$ (I. Pratiwi, Aziz, \& Kusumastuti, 2018). Yet, the unstable ciprofloxacin antibiotic is absorbed by the digestive tract (Y. Pratiwi \& Swantari, 2017).

Based on the description above, the researcher wants to test the effectiveness of antibiotics from Turmeric rhizome extract toward the proliferation of Bacillus cereus with Ciprofloxacin as a comparison.

\section{RESEARCH METHOD}

Method used was experimental method with post test only design. In this research design, the interventions which had been carried out were then carried out measurements (observations) or post-tests of the results. Treatment was as independent variables and results as dependent variables.

The location of the research was conducted at the Faculty of Medicine of Universitas Prima Indonesia, part of the clinical pathology laboratory, Medan, North Sumatera and the time the research was in September.

Sampling used a purposive sampling technique. The extract used was turmeric rhizome extract. The samples tested were obtained at Gambir Market, Tembung.

Research tools were calipers, weighing devices, autoclaves, stirring rods, petri dishes, erlenmeyer tubes, measuring cups, incubators, flannel cloths, cotton, Ose needles, filter woods, measuring flasks, bunsen burners, ovens, paper disks, markers, test tubes, labels, aluminum coils, rotary evaprotators, micropipets, and fial bottles.

The research materials were rhizome of turmeric (Curcuma domestica VALET) 2000 grams $(2 \mathrm{~kg}), 70 \%$ alcohol, DMSO, Bacillus cereus bacteria and Ciprofloxacin antibacterial.

Tools which would be used should be sterilized. The oven is used for dry heat sterilization and sterilization tools in this research made of glass using an oven with a temperature of $170 \mathrm{oC}$ for 2 hours. Whereas in wet heat, it used an autoclave with a temperature of $1210 \mathrm{C}$ for 15 minutes.

Fresh turmeric was cleaned using running water. Furthermore, turmeric is divided into several pieces. Then dry it in a place that is not exposed to direct sunlight. Thus, after the material has been dried and then smoothed, the material became powdery form.

The calculation of Turmeric Rhizome Flour Fluid before being drying was 2000 gr. Turmeric rhizome powder was $200 \mathrm{~g}$. $70 \%$ of alcohol volume was needed:

$\mathrm{V}=\mathrm{B} /(\mathrm{Bj} 70 \%$ alcohol $)=(2000 \mathrm{~g}) /$ $(0.884 \mathrm{~g} / \mathrm{ml})=2262.4 \mathrm{ml}$

75 parts of extract fluid: $75 / 100 \times 2262$ $\mathrm{ml}=1696.5 \mathrm{ml}$

25 parts of extract fluid: $25 / 100 \times 2262$ $\mathrm{ml}=565.5 \mathrm{ml}$

Making Turmeric Rhizome Extract

1. Turmeric powder is weighed as much as 200 grams, put in a container and pour 75 parts of liquid filter (1696.5 $\mathrm{ml})$.

2. Cover the container, wait 5 days and protect from the sun while stirring several times.

3. After 5 days, the pulp is rinsed with the remaining 25 parts of filter liquid until $2262.4 \mathrm{ml}$ is obtained.

4. Then left for 2 days, then pour and transfer into a container.

5. Then the maceration is evaporated using a Rotary evaporator $\left(60^{\circ} \mathrm{C}-65^{\circ} \mathrm{C}\right)$ until a thick turmeric rhizome extract is obtained.

Making Extract Sample

1) $25 \%$ Concentration $=25 \mathrm{gr} / 100 \mathrm{~mL}$ $=0,25 \mathrm{gr} / 1 \mathrm{~mL}$

2) $50 \%$ concentration $=50 \mathrm{gr} / 100 \mathrm{~mL}=$ $0,5 \mathrm{gr} / 1 \mathrm{~mL}$

3) $75 \%$ Concentration $=75 \mathrm{gr} / 100 \mathrm{~mL}$ $=0,75 \mathrm{gr} / 1 \mathrm{~mL}$

4) $100 \%$ concentration $=100$ gr turmeric extract.

Making Media 
1. Agar Nutrient Media (NA) is by pouring 28 gr of Nutrient Agar (NA) and $1 \mathrm{~L}$ aquadest into Erlenmeyer and then make into a form of solution by heating, then use an autoclave with a temperature of $120^{\circ} \mathrm{C}$ sterilized for 15 minutes.

2. Media Nutrient Broth (NB) is by inserting 13 grams of Nutrient Broth (NB) and $1 \mathrm{~L}$ aquadest into Erlenmeyer, then heated until dissolved. Furthermore, further sterilization with an autoclave sterilization is carried out at a temperature of $120^{\circ} \mathrm{C}$ for 15 minutes. 30-45 degrees until the shape becomes solid at room temperature and stored in the refrigerator at $5^{\circ} \mathrm{C}$.

Preparing Inoculum Bacillus cereus colony was taken with a sterile OSE from the existing culture stock and then combined to $10 \mathrm{~mL}$ NB. Thus, the colony was suspended, and incubated at $35 \pm 20 \mathrm{C}$. Spectrophotometer (Depkes RI, 1995).

Antibacterial Effectiveness Test

1) Plant in in a sterile room in laminar air flow near Bunsen.

2) Take bacterial suspension from NB media on a $0.1 \mathrm{~mL}$ micropipet test tube. Treatmet is conducted near Bunsen so that bacteria in the test tube do not come out or vice versa.

3) Then transfer the bacterial suspension to a petri dish and fill $15 \mathrm{~mL}$ of NA media, then homogenize by forming the number 8 .

4) Place the disc paper which has been given drops of extract material at different concentrations and a solution of Ciprofloxacin and aquadest on the surface of NA media that has been planted with bacteria. Then Incubation $\left(37^{0} \mathrm{C}\right)$ for $18-24$ hours.

5) The clear zone contained is measured as the inhibition zone around the disc paper with calipers.

\section{Data Analysis}

Data analysis of antibacterial effectiveness test result statistically analyzed. The software used was SPSS with the One Way Annova test with the Post Hoc Test Tukey.
H0: There is no difference in effect between turmeric rhizome extract and Ciprofloxacin.

Ha: There is a difference in effect between turmeric rhizome extract and Ciprofloxacin.

\section{RESULT AND DISCUSION}

Process of collecting data was conducted in September 2019 at the UNPRI Laboratory by using turmeric rhizome extract samples toward the bacterium Bacilus cereus ATCC 14579. Data collected and examined, it can be concluded the results of the study below.

The diameter of the turmeric rhizome inhibitory zone in contact with Bacillus cereus ATCC 14579.

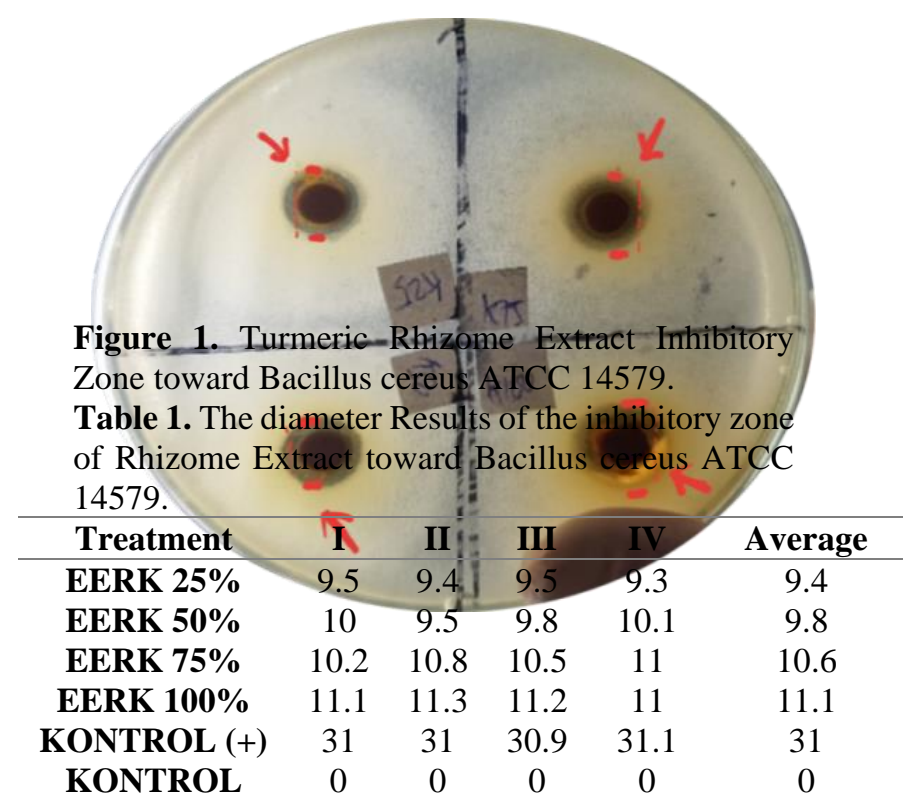

$(-)$

Information

EERK: turmeric rhizome ethanol extract

Inhibitory produced by turmeric rhizome extract by using a sensitivity test showed that there was an inhibitory zone in the area ofpaper discs which had dropped several concentrations. The calipers were used to measure the power of the inhibition zone. To measure the vertical and horizontal parts and then the average is calculated, it was conducted on each treatment and the inhibition zone is 
obtained as shown in the figure and table below.

Based on the table and figure above, it shows that the results of research which uses turmeric rhizome extract toward the bacterium Bacillus cereus each treatment obtains different results. At a concentration of $25 \%$, it had an average of $9.4 \mathrm{~mm}$, at a concentration of $50 \%$ it has an average of $9.8 \mathrm{~mm}$, at a concentration of $75 \%$, it had an average of $10.6 \mathrm{~mm}$, with $100 \%$ concentration having an average of 11.1 $\mathrm{mm} .25 \%$ was the lowest inhibitory zone diameter at treatment, the IV was $9.3 \mathrm{~mm}$ and the highest diameter was treated at II with $100 \%$ inhibition.

The positive control used was Ciprofloxacin with a inhibition zone of 31.0 $\mathrm{mm}$ and the negative control used was Aquadest with a inhibition zone of $0 \mathrm{~mm}$. This shows that the higher the concentration of turmeric rhizome extract, the greater the effectiveness as an antibacterial, as evidenced by the extent of inhibition zones

Ciprofloxacin Inhibition Zone Diameter toward Bacillus cereus ATCC 14579 Bacteria.

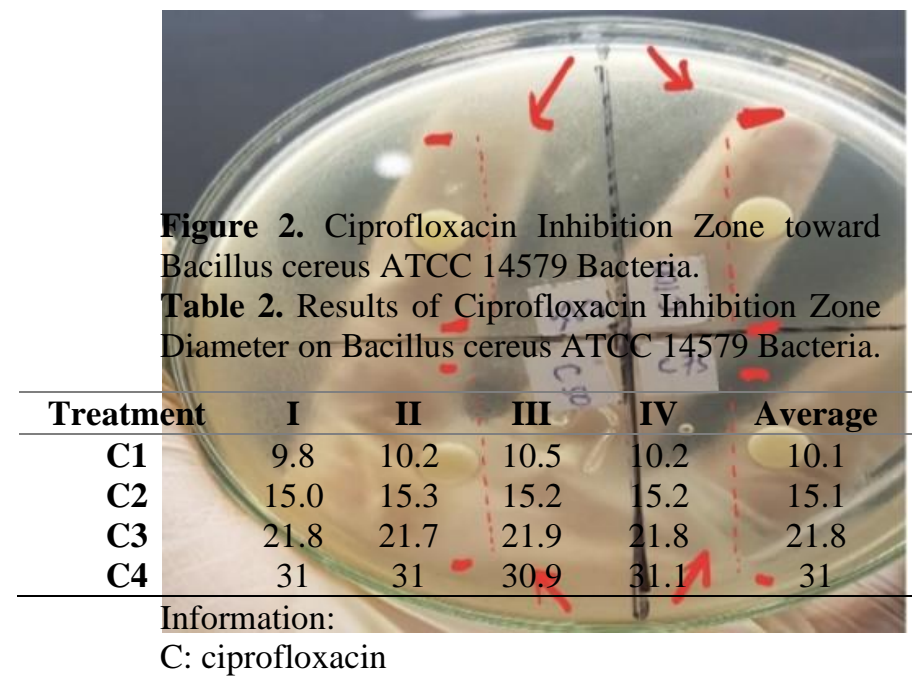

The inhibitory power of Ciprofloxacin toward Bacillus cereus ATCC 14579 could be determined when the inhibitory zone had been formed by looking at it, and measuring it with a calipers by measuring the vertical and horizontal parts and then the average was calculated. It was conducted at each treatment and the zone was obtained Block like the picture and table below.

Bacillus cereus every treatment given to get different results - different. At a concentration of $25 \%$, it haf an average of $10.1 \mathrm{~mm}$, at a concentration of $50 \%$ had an average of $15.1 \mathrm{~mm}$, at a concentration of $75 \%$ has an average of $21.8 \mathrm{~mm}$, at $100 \%$ concentration. There was a diameter of the inhibition zone power of $310 \mathrm{~mm}$. at the lowest diameter of the inhibitory zone, it was found a diameter of $10.1 \mathrm{~mm}$ conducted at the first treatment with a concentration of $25 \%$ and the highest inhibitory zone diameter of $31.1 \mathrm{~mm}$ at the IV treatment at a concentration of $100 \%$ was $25 \%$ on the treatment the. I was 10.1 $\mathrm{mm}$ and the highest inhibitory zone diameter is $100 \%$. The negative control used was Aquadest with a inhibition zone of $0 \mathrm{~mm}$.

Comparison of the Inhibition Zone of Turmeric Rhizome Extract with Ciprofloxacin.

From the comparison of turmeric extract zone with ciprofloxacin, it is known that:

$\mathrm{HO}$ : There is no difference in the effectiveness of turmeric rhizome extract with Ciprofloxacin.

$\mathrm{Ha}$ : There are differences in the effectiveness of turmeric rhizome extract with Ciprofloxacin.

From the One Way Anova test results, it was obtained a value of $\mathrm{P}=0,000$ which means $\mathrm{p}<\alpha$ in which $\alpha<0.05$ then $\mathrm{Ha}$ is accepted and $\mathrm{Ho}$ is rejected. It can be concluded that there are differences in the effectiveness of turmeric extract with ciprofloxacin toward Bacillus cereus. Then it was to find out whether there is a difference from each treatment given to bacteria carried out further analysis of Post Hoc Test with Tukey's choice. After conducting the Post Hoc Test, it was found that there were significant differences from each treatment given with a 95\% confidence index. In the Post Hoc Tukey test it was also found that the $25 \%$ 
ciprofloxacin treatment against Bacillus cereus, the effectiveness obtained was above $50 \%$ turmeric rhizome extract and was below $75 \%$ turmeric rhizome extract. As for the concentration of ciprofloxacin $50 \%, 75 \%$, and $100 \%$ have very good effectiveness on the Bacillus cereus $95 \%$ confidence index.

\section{Discussion}

Based on research data result obtained that there is effectiveness of turmeric rhizome extract against Bacillus cereus and there was a difference in the effectiveness of turmeric rhizome extract with Bacillus cereus ciprofloxacin. The intended effectiveness was the presence of inhibition zones in the surrounding paper discs. With calipers can be measured the inhibitory zone power that has been formed to determine the effectiveness of the treatment. To assess the effectiveness of turmeric extract, greenwood classification is used as shown in the table below.

Table 3. Responses Classification to inhibiting bacterial growth.

\begin{tabular}{cc}
\hline $\begin{array}{c}\text { Averenge of inhibition } \\
\text { zone diameters }\end{array}$ & $\begin{array}{c}\text { Growth inhibition } \\
\text { >20 } \mathbf{~ m m}\end{array}$ \\
$\mathbf{1 6 - 2 0 ~} \mathbf{~ m m}$ & response \\
$\mathbf{1 0 - 1 5} \mathbf{~ m m}$ & Strong \\
$<\mathbf{1 0} \mathbf{~ m m}$ & Weak \\
\hline
\end{tabular}
Source: (Firdaus, 2014)

The concentration of $100 \%$ in turmeric extract was the best concentration which inhibited the growth of Bacillus cereus bacteria. This was shown in the second treatment showing a diameter of $11.3 \mathrm{~mm}$ which was categorized as a weak inhibitory zone and a concentration of $25 \%$ in turmeric extract is the worst concentration inhibiting the growth of Bacillus cereus bacteria. This was shown in the fourth treatment showing a diameter of $9.3 \mathrm{~mm}$ which was categorized as an ineffective inhibition zone.

In ciprofloxacin, a $100 \%$ concentration was the best. This was shown in the fourth treatment showing a diameter of $31.1 \mathrm{~mm}$ which was categorized as a strong inhibitory zone and a concentration of $25 \%$ was a poor concentration. This was shown in the first treatment showing a diameter of $10.1 \mathrm{~mm}$ categorized as a weak inhibitory zone. The control (-) used was aquadest which did not show an inhibitory zone toward the Bacillus Cereus bacteria.

This caused the formation of inhibitory zones because the turmeric rhizome had active compounds that were antimicrobial. Turmeric rhizome had active compounds such as essential oils and yellow dyes (curcuminod). Curcuma domestica VALET was a plant that was able to treat infectious diseases.

In this research, it was found that the formation of inhibitory zones in turmeric rhizome extract increased sequentially from the lowest to highest concentrations ranging from $9.4 \mathrm{~mm}$ to $11.1 \mathrm{~mm}$. Antibacterial was a beneficial effect found in turmeric rhizome extract to Bacillus cereus bacteria and this study was in line with existing research of (Yuliati, 2016), turmeric rhizome extracts studied starting from concentrations of $15 \%, 30 \%, 50 \%$, $75 \%$ and $100 \%$ of the bacteria Bacillus sp and Shigella dysentriae both had the best inhibitory zone effect is $14.7 \mathrm{~mm}$ which is relatively weak. (Pangemanan et al., 2016), turmeric rhizome extract studied began with concentrations of $5 \%, 10 \%, 20 \%$, and $40 \%$ of the positive bacteria Staphylococcus aureus gram and Pseudomonas sp gram negative both of which had inhibitory zone effects which were best $15 \mathrm{~mm}$ at a concentration of $40 \%$, which was relatively weak.

Curcumin which has an antimicrobial effect contains polyphenol compounds and it is good for inhibiting thiolase enzymes (sulfhydryl enzymes) as a result of the formation of protein denaturation processes. In addition, polyphenols are compounds which can dissolve in fat. Thus, it can damage the structure of bacterial cell membranes. Essential oils contain terpenoids which work as an antibacterial through the process of destroying the structure of bacterial cell membranes.

According to (Cushine, Cushine, \& Lamb, 2014), Alkaloid as an anti-bacterial 
works by damaging the constituent constituents of peptidoglycan in bacterial cells by damaging the structure of the outer membrane and cytoplasm, resulting in leakage of cytoplasmic contents ${ }^{(15)}$.

According to (Cushine et al., 2014), flavonoids as antibacterial work processes of flavonoids are divided into 3, as follow:

1. In nucleic acids, there is a buildup of bases to suppress the formation of nucleic acids.

2. The formation of extracellular flavonoid-protein complexes to suppress cell membrane function. This can damage the permeability of cell membranes and suppress the bond between the enzyme ATPase and phospholiphase.

3. Besides, it suppress the process of energy metabolism and suppress cytochrome $\mathrm{C}$ reductase.

It was different with research by (Muadifah, Eka Putri, \& Latifah, 2019), that turmeric rhizome extract as an antibacterial at a concentration of $45 \%$, $55 \%, 65 \%$, and $75 \%$ toward gram-positive Staphylocuccus aureus bacteria. The best inhibitory zone effect is $11 \mathrm{~mm}$ at $45 \%$ concentration classified as weak.

\section{CONCLUSION}

Turmeric rhizome extract has antibacterial effectiveness toward bacteria Bacillus cereus ATCC 14579. Turmeric rhizome extract has a weak effect as inhibitory zone power against Bacillus cereus ATCC 14579 bacteria according to inhibition zone classification, the best concentration is $100 \%$ average diameter of inhibition zone $11.1 \mathrm{~mm}$. Based on the inhibition zone classification, ciprofloxacin has a strong effect on the bacterium Bacillus cereus ATCC 14579 as a growth inhibitor of the bacteria. $100 \%$ is the best concentration choice because there is an average inhibition zone diameter of 31.0 $\mathrm{mm}$. The analysis test is carried out with the One Way Annova test and $\mathrm{P}=0,000$ was obtained, which means $\mathrm{p}<\alpha$ where $\alpha<0.05$ then $\mathrm{Ha}$ is accepted and Ho is rejected. There are differences in the effectiveness of turmeric rhizome extract with ciprofloxacin toward Bacillus cereus ATCC 14579 bacteria.

\section{Acknowledgment}

Researchers give their gratitude to Head of the Prima Indonesia University Foundation, Dr. dr. I Nyoman Ehrich Lister, M. Kes., AIFM., Rector of the University of Indonesia Prima Dr. Chrismis Novalinda Ginting, M. Kes., And Dean of the Faculty of Medicine Dr. Lnda Chiuman, M.K.M., AIFO-K who have facilitated the form of facilities and infrastructure so that this research can be completed properly. The researchers also thank the supervisor lecturer Dr. Yolanda Eliza Putri Lubis, M.K.M., M.Biomed, and to Mrs. Rini Octavia as a laboratory assistant and to the team in presenting this research.

\section{REFERENCE}

Balittro, \& Hartati, S. Y. (2013). KHASIAT KUNYIT SEBAGAI OBAT TRADISIONAL DAN MANFAAT LAINNYA. 19(2).

Brooks, et al. (2013). Mikrobiologi Kedokteran Jawetz, Melnick, \& Adelberg. In EGC. https://doi.org/10.1017/CBO9781107 415324.004

Cushine, T. ., Cushine, B., \& Lamb, A. . (2014). Alkaloids: an overview of their antibacterial, antibioticenhancing and antivirulence activities. International Journal of Antimicrobial Agent, 44(5), 377-386.

Depkes RI. (1995). Farmakope Indonesia edisi IV. In Departemen Kesehatan Republik Indonesia.

Firdaus, T. (2014). Efektifitas ekstrak bawang dayak (Eleutherine palmifolia) dalam menghambat pertumbuhan bakteri Staphylococcus aureus. Jakarta, (1), 1-50. https://doi.org/http://repository.uinjkt. ac.id/dspace/bitstream/123456789/27 277/1/TAZKIYATUL\%20FIRDAUS -FKIK.pdf

Kementerian Kesehatan RI. (2008). Daftar Obat Esensial Nasional 2008. Departemen Kesehatan Republik 
Indonesia.

https://doi.org/10.1007/s13398-014-

0173-7.2

Muadifah, A., Eka Putri, A., \& Latifah, N. (2019). AKTIVITAS GEL EKSTRAK RIMPANG KUNYIT (Curcuma domestica Val) TERHADAP BAKTERI Staphylococcus aureus. Jurnal SainHealth, 3(1), 45-54.

Mutiah, R. (2015). EVIDENCE BASED KURKUMIN DARI TANAMAN KUNYIT (Curcuma longa) SEBAGAI TERAPI KANKER. 1(1), 28-41.

Nadifah, F., Farida Muhajir, N., \& Retnoningsih, F. (2018). Daya Hambat Minyak Atsiri Rimpang Kunyit terhadap Pertumbuhan Candida Albicans In Vitro. Jurnal Vokasi Kesehatan, 4(1), 1. https://doi.org/10.30602/jvk.v4i1.124

Pangemanan, A., . F., \& Budiarso, F. (2016). Uji daya hambat ekstrak rimpang kunyit (Curcuma longa) terhadap pertumbuhan bakteri Staphylococcus aureus dan Pseudomonas sp. Jurnal E-Biomedik, 4(1).

https://doi.org/10.35790/ebm.4.1.201 6.10840

Pratiwi, I., Aziz, S., \& Kusumastuti, E. (2018). Rasionalitas Penggunaan Antibiotik Ciprofloxacin pada Penderita Demam tifoid. 4(2), 46-51.

Pratiwi, Y., \& Swantari, A. (2017). Perbandingan Penggunaan Obat Antibiotik (Amoxicilin, Cefradroxil, dan Ciprofloxacin) di Puskesmas $X$ Kabupaten Kudus. 1(1), 1.

Rukmana, R. (1995). kunyit. Yogyakarta: Kansius.

Widyaningrum, H. (2011). Kitab Tanaman Obat Nusantar (H. (2011) K. T. O. N.
Widyaningrum, ed.).

Yuliati, Y. (2016). UJI EFEKTIVITAS EKSTRAK KUNYIT SEBAGAI ANTIBAKTERI DALAM PERTUMBUHAN Bacillus sp dan Shigella dysentriae SECARA IN VITRO. Jurnal Profesi Medika: Jurnal Kedokteran Dan Kesehatan, 10(1).

https://doi.org/10.33533/jpm.v10i1.11

Yusnidar. (2017). Analisa Sakarin dalam Jamu Kunyit Asam yang Dijual di Malioboro dan di pasar Beringharja Yogyakarta. 10(1). 